\title{
ANALISIS PENGARUH KENAIKAN HARGA PENGAWET TERHADAP KEGIATAN PRODUKSI INDUSTRI KOSMETIK MENGGUNAKAN METODE UJI REGRESI SEDERHANA (Studi Kasus : PT Paragon Technology And Innovation)
}

\author{
Hendro Waryanto ${ }^{1, a)}$ Radita Pratiwi ${ }^{2, b)}$ \\ ${ }^{1,2}$ Program Studi Matematika FMIPA Universitas Pamulang \\ Email: a)hendrowaryanto@gmail.com ${ }^{\text {b)} 2014100162 @ u n p a m . a c . i d}$
}

\begin{abstract}
ABSTRAK
Tujuan dalam penelitian ini yaitu untuk mengetahui pengaruh kenaikan harga pengawet terhadap kegiatan produksi di industri kosmetik dan mengetahui bentuk persamaan regresi dan persamaan korelasi antara kenaikan harga pengawet terhadap kegiatan produksi di industri kosmetik. Metode Penelitian ini menggunakan metode survei. Hasil yang diiperoleh dari analisisi dan pembahasan yaitu adanya pengaruh kenaikan harga pengawet terhadap kegiatan produksi di industri kosmetik sebesar 0,044 dan persamaan untuk mengetahui apakah terdapat pengaruh antara kenaikan harga pengawet terhadap kegiatan produksi

$$
Y=-2,104 \mathrm{E}-7 X_{1}+1,341 \text {. }
$$
\end{abstract}

Kata kunci: Regresi, Industri

\section{ABSTRACT}

The purpose of this study is to determine the effect of the increase in preservative prices on production activities in the cosmetics industry and determine the shape of the regression equation and the correlation equation between preservative price increases on production activities in the cosmetics industry. Method This study uses a survey method. The results obtained from the analysis and discussion are the effect of the increase in preservative prices on production activities in the cosmetics industry by 0.044 and the equation to find out whether there is an influence between the increase in preservative prices on production activities

$Y=-2,104 E-7 X 1+1,341$.

Keywords: Regression, Industry

\section{PENDAHULUAN}

\subsection{Latar Belakang}

Dalam era globalisasi pada saat ini, kemajuan bidang kesehatan semakin melesat dari waktu ke waktu, khususnya pada bidang Kosmetologi. Dengan majunya era globalisasi ini, Kosmetik tidaklah menjadi sesuatu yang mewah bahkan kosmetik menjadi hal yang wajib bagi umat manusia, khususnya kaum hawa. Pada abad ke-19, 
pemakaian kosmetik mulai mendapat perhatian, yaitu selain untuk kecantikan juga untuk kesehatan. Menurut Tranggono sambil mengutip Jellinek dkk (1970) perkembangan ilmu kosmetik serta industrinya baru dimulai secara besar-besaran pada abad ke-20.

Kosmetik saat ini telah menjadi kebutuhan manusia yang tidak bisa dianggap sebelah mata lagi. Dan sekarang semakin terasa bahwa kebutuhan adanya kosmetik yang beraneka bentuk dengan ragam warna dan keunikan kemasan serta keunggulan dalam memberikan fungsi bagi konsumen menuntut industri kosmetik untuk semakin terpicu mengembangkan teknologi yang tidak saja mencakup peruntukannya dari kosmetik itu sendiri namun juga kepraktisannya didalam penggunaannya.

Tidak bisa dipungkiri bahan baku pengawet merupakan salah satu bahan pokok paling penting dalam sebuah industri. Mengingat perannya sebagai penghambat atau pencegah kerusakan produk dari mulai waktu produksi sampai pemberian pada konsumen. Sebagian besar dapat mengalami kerusakan karena mikroorganisme. Banyak perubahan yang terjadi dalam suatu produk misalnya perubahan emulsi, perubahan sistem viskositas, adanya creaming atau koalesens. Sediaan yang berwarna jernih dapat berubah menjadi berselaput. Wadah juga dapat dapat bereaksi dengan produk. Warna dari produk dapat berubah karena perubahan temperatur dan pemaparan cahaya dan fase minyak yang terdapat dalam sediaan kosmetik menjadi berbau tengik. Mikroorganisme dapat muncul dengan tiba-tiba, tipe reaksi dan interaksi yang dapat terjadi dimana ahli kimia kosmetik harus mengantisipasi problem diatas dengan teknik formulasi, produksi dan pewadahan yang baik. Pengawet merupakan bahan yang dapat mencegah atau mematikan pertumbuhan mikroorganisme.

\subsection{Rumusan Masalah}

Berdasarkan latar belakang dan indikasi masalah maka dapat dirumuskan masalah yang akan di analisis yaitu :

1. Apakah ada pengaruh kenaikan harga pengawet terhadap kegiatan produksi di industri kosmetik?

2. Bagaimana bentuk persamaan regresi dan korelasi antara kenaikan harga pengawet dengan kegiatan produksi di industri kosmetik?

\subsection{Tujuan Penelitian}

Tujuan dalam penelitian ini yaitu :

1. Untuk mengetahui pengaruh kenaikan harga pengawet terhadap kegiatan produksi di industri kosmetik.

2. Mengetahui bentuk persamaan regresi dan persamaan korelasi antara kenaikan harga pengawet terhadap kegiatan produksi di industri kosmetik. 


\section{TINJAUAN PUSTAKA}

\subsection{Jenis dan Sumber Data}

Dalam penelitian ini penulis menggunakan penelitian kuantitatif, karena data yang diperoleh nantinya berupa angka. Dari angka yang diperoleh akan dianalisis lebih lanjut dalam analisis data.

Sumber data berasal dari data sekunder yaitu merupakan data primer yang telah diolah lebih lanjut dan disajikan baik pihak pengumpul data primer maupun oleh pihak lain (Umar, 2001 : 69). Data yang diperoleh dari suatu kegiatan produksi di PT Paragon Technology And Innovation dengan memperhatikan konsentrasi atau dosis pengawet yag digunakan pada item tertentu. Juga bersumber pada literatur, artikel, jurnal serta situs internet yang berkenaan dengan penelitian yang dilakukan.

\subsection{Metode Pengumpulan Data}

Data yang digunakan dalam laporan ini merupakan dosis pengawet pada setiap item yang berbeda. Data pada siklus kenaikan harga bahan baku. Serta jadwal kegiatan produksi PT Paragon Technology And Innovation pada bulan Juli - Agustus 2017.

\subsection{Metode Penelitian}

Metode penelitian adalah cara yang digunakan oleh peneliti mengumpulkan data penelitiannya (Arikunto, 2002 : 136). Sugiyono (2006) menjelaskan bahwa metode penelitian diartikan sebagai cara ilmiah yang digunakan untuk mendapatkan data yang objektif, valid, dan reliable, dengan tujuan dapat ditemukan, dibuktikan dan dikembangkan suatu pengetahuan, sehingga dapat digunakan untuk memahami, memecahkan, dan mengatisipasi masalah.

Penelitian ini menggunakan desain penelitian dengan metode asosiatif. Karena tujuan penelitian ini adalah untuk menjelaskan hubungan sebab akibat dalam bentuk pengaruh antara variabel melalui pengujian hipotesis. Menurut Sugiono (2004:1) penelitian asosiatif adalah penelitian yang bertujuan untuk mengetahui hubungan antara dua variabel atau lebih. Dengan penelitian ini maka dapat dibangun suatu teori yang dapat berfungsi untuk menjelaskan, membuat prakiraan dan mengontrol suatu gejala.

Variabel Penelitian merupakan semua yang di tetapkan oleh peneliti untuk di pelajari sehingga memperoleh informasi tentang hal tersebut kemudian dapat di tarik kesimpulannya (Sugiyono, 2006).

Dalam penelitian ini di bedakan menjadi dua variabel yaitu variabel bebas (independent) dan variabel terikat (dependent). Kedua variabel tersebut adalah sebagai berikut :

1. Variabel X

Variabel $\mathrm{x}$ atau variabel independent atau variabel bebas adalah variabel yang diteliti pengaruhnyaatau variabel yang diduga memberikan suatu pengaruh. Dalam penelitian ini yang menjadi variabel $\mathrm{x}$ adalah kenaikan harga pengawet. 


\section{Variabel Y}

Variabel Y atau variabel dependent atau variabel terikat adalah variabel yang diramalkan atau variabel yang dicari. Dalam penelitian ini variabel y adalah kebutuhan pengawet pada kegiatan produksi.

\subsection{Metode Analisis Data}

Metode analisis data adalah suatu metode yang digunakan untuk mengolah hasil penelitian guna memperoleh suatu kesimpulan. Dengan melihat kerangka pemikiran teoritis, maka teknik analisis data yang digunakan dalam penelitian ini adalah metode analisis asosiatif. Dalam penelitian ini analisis yang digunakan untuk mengetahui pengaruh kenaikan harga pengawet terhadap kegiatan produksi di PT Paragon Technology And Innovation, menggunakan analisis korelasi dan analisis regresi linear sederhana.

Untuk memperoleh analisis yang tepat, maka menggunakan metode analisis kenormalan data, analisis korelasi, dan analisis regresi.

\subsubsection{Analisis Kenormalan Data}

Analisis Kenormalan Data atau Uji Normalitas adalah sebuah uji yang dilakukan dengan tujuan untuk menilai sebaran data pada sebuah kelompok data atau variabel, apakah sebaran data tersebut berdistribusi normal atau tidak.

Uji normalitas berguna untuk menentukan data yang telah dikumpulkan berdistribusi normal atau diambil dari populasi normal. Metode klasik dalam pengujian normalitas suatu data tidak begitu rumit. Berdasarkan pengalaman empiris beberapa pakar statistik, data yang banyaknya lebih dati 30 angka ( $>30$ ), maka sudah dapat diasumsikan berdistribusi normal. Biasa dikatakan sebagai sampel besar.

Namun untuk memberikan kepastian, data yang dimiliki berdistribusi normal atau tidak, sebaiknya digunakan uji normalitas. Karena belum tentu data yang lebih dari 30 bisa dipastikan berdistribusi normal, demikian sebaliknya data yang banyaknya kurang dari 30 belum tentu tidak berdistribusi normal, untuk itu perlu suatu pembuktian. Uji statistik normalitas yang dapat digunakan diantaranya Chi-square, Kolmogorov Smirnov, Lilliefors, Shapiro Wilk, Jarque Bera.

Analisis kenormalan data harus dilakukan sebelum melakukan analisis yang lain, karena analisis kenormalan data berfungsi untuk melihat data tersebut normal atau tidak. Langkah - langkah dalam melakukan analisis data adalah sebagai berikut :

1. Distribusi Frekuensi

2. Distribusi Deskriptif

\subsubsection{Analisis Korelasi}

Korelasi merupakan teknik analisis yang termasuk dalam salah satu teknik pengukuran asosiasi atau hubungan (measures of association). Dua variabel dikatakan berasosiasi jika perilaku variabel yang satu mempengaruhi variabel yang lain. Jika tidak terjadi pengaruh, maka kedua variabel tersebut disebut independen. 
Kuat lemah hubungan diukur diantara jarak (range) 0 sampai dengan 1. Korelasi mempunyai kemungkinan pengujian hipotesis dua arah (two tailed). Korelasi searah jika nilai koefisien korelasi diketemukan positif; sebaliknya jika nilai koefisien korelasi negatif, korelasi tersebut tidak searah. Yang dimaksud dengan koefisien korelasi ialah suatu pengukuran statistik kovariasi atau asosiasi antara dua variabel. Jika koefisien korelasi diketemukan tidak sama dengan nol (0), maka terdapat hubungan antara dua variabel tersebut. Jika koefisien korelasi diketemukan +1 , maka hubungan tersebut disebut sebagai korelasi sempurna atau hubungan linear sempurna sengan kemiringan (slope) positif. Sebaliknya, jika koefisien korelasi diketemukan -1, maka hubungan tersebut disebut sebagai korelasi sempurna atau hubungan linear sempurna dengan kemiringan (slope) negatif.

Dalam korelasi sempurna tidak diperlukan lagi pengujian hipotesis, karena kedua variabel mempunyai hubungan linear sempurna. Artinya variabel $\mathrm{X}$ mempunyai hubungan sangat kuat dengan variabel Y. Jika korelasi sama dengan nol (0), maka tidak terdapat hubungan antara kedua variabel tersebut.

Untuk melakukan pengujian hipotesis koefisien korelasi langkah pertama adalah merumuskan hipotesis. Untuk pengujian hipotesis satu sisi adalah :

$\mathrm{H}_{0}: \rho=0$ (Tidak ada hubungan yang signifikan antara variabel $\mathrm{X}$ dengan $\mathrm{Y}$ )

$\mathrm{H}_{1}: \rho>0$ (Ada hubungan positif antara variabel $\mathrm{X}$ dengan $\mathrm{Y}$ ) atau

$\mathrm{H}_{1}: \rho<0$ (Ada hubungan negatif antara variabel $\mathrm{X}$ dengan $\mathrm{Y}$ )

Sedangkan untuk pengujian hipotesis dua sisi adalah :

$\mathrm{H}_{0}: \rho=0$ (Tidak ada hubungan yang signifikan antara variabel $\mathrm{X}$ dengan $\mathrm{Y}$ )

$\mathrm{H}_{1}: \rho \neq 0$ (Ada hubungan yang signifikan antara variabel $\mathrm{X}$ dengan $\mathrm{Y}$ )

Kemudian pada langkah kedua yaitu dengan menentukan nilai probabilitas atau signifikansi ( ) tx,tx/2 $\rightarrow$ Degree Of Freedom $(\mathrm{DF})=\mathrm{n}-\mathrm{k}(\mathrm{k}=$ banyaknya semua variabel)

Langkah ketiga dengan menghitung niai uji statistik atau thitung (to) dengan rumus

to $=\frac{r \sqrt{n-k}}{\sqrt{1-r^{2}}}$

Selanjutnya dengan membuat kesimpulan. Untuk uji satu sisi (one-tailed test) :

Jika to $>\mathrm{t}$, maka $\mathrm{H}_{0}$ ditolak dan $\mathrm{H}_{1}$ diterima.

Jika to $\leq \mathrm{t}$, maka Ho diterima atau,

Jika to $<-\mathrm{t}$, maka Ho ditolak.

Jika to $\geq-\mathrm{t}$, maka $\mathrm{H} 0$ diterima.

Untuk uji dua sisi (two-tailed test) yaitu :

Jika to $>t_{x} / 2$ atau to $<-t_{x} / 2$, maka $\mathrm{H}_{0}$ ditolak dan $\mathrm{H}_{1}$ diterima jika $-\mathrm{t}_{\mathrm{x} / 2} \leq \mathrm{to}_{\mathrm{a}} \leq \mathrm{t}_{\mathrm{x} / 2}$, maka $\mathrm{H}_{0}$ diterima. 


\subsubsection{Analisis Regresi}

Regresi merupakan prosedur yang berfungsi untuk melihat hubungan linear antara satu variabel yang diidentifikasi sebagai variabel independen atau bebas dengan variabel lain yang diidentifikasi sebagai variabel dependen atau tergantung. Dalam memahami regresi linear secara manual kita perlu memahami hal-hal berikut :

\begin{tabular}{|c|c|c|c|}
\hline \multicolumn{2}{|r|}{ asi (parameter) } & $: Y^{\prime}=\alpha+\beta X+\varepsilon$ & $; \varepsilon$ \\
\hline \multicolumn{2}{|c|}{ Sampel } & $: Y^{\prime}=a+b X+e$ & ; e \\
\hline \multicolumn{4}{|c|}{ Arti } \\
\hline$Y^{\prime}$ & \multicolumn{3}{|c|}{$\begin{aligned}= & \text { Variabel tergantung atau dependen atau disebut juga variabel kriteria, } \\
& \text { yaitu variabel yang nilainya akan diprediksi. }\end{aligned}$} \\
\hline & \multicolumn{3}{|c|}{$\begin{aligned}= & \text { Titik potong garis regresi pada sumbu vertikal }(\mathrm{Y}) \text { atau disebut intersep } \\
& \text { atau kosntanta, yaitu nilai } \mathrm{Y} \text { yang diprediksikan bila nilai } \mathrm{X}=0\end{aligned}$} \\
\hline$b$ & \multicolumn{3}{|c|}{$\begin{aligned}= & \text { Tingkat kemiringan garis regresi atau koefisien regresi, yaitu besarnya } \\
& \text { perubahan nilai } Y^{\prime} \text { bila nilai } \mathrm{X} \text { berubah sebesar satu satuan. }\end{aligned}$} \\
\hline$X$ & \multicolumn{3}{|c|}{$\begin{aligned}= & \text { Variabel bebas atau independen atau disebut juga sebagai prediktor, } \\
& \text { Yaitu variabel yang digunakan untuk memprediksi nilai Y. }\end{aligned}$} \\
\hline & \multicolumn{3}{|c|}{$\begin{aligned} &= \text { Epsilon atau error pada garis regrresi, merupakan selisih nilai } \mathrm{Y} \text { yang d } \\
& \text { prediksikan dengan nilai } \mathrm{Y} \text { yang diperoleh atau disebut juga sebagai } \\
& \text { residual }\left(\mathrm{Y}^{\prime}-\mathrm{Yo}_{\mathrm{O}}\right)\end{aligned}$} \\
\hline
\end{tabular}

Pada koefisien regresi pun dapat dilakukan pengujian hipotesis dengan menggunakan Uji-t dengan langkah pertama yaitu dengan merumuskan hipotesis. Untuk pengujian satu sisi :

$\mathrm{H}_{0}: \beta=\beta$ o (Variabel $\mathrm{X}$ tidak berpengaruh terhadap variabel $\mathrm{Y}$ secara signifikan)

$\mathrm{H}_{1}: \beta \neq \beta$ o (Variabel $\mathrm{X}$ berpengaruh terhadap variabel Y secara signifikan)

Sedangkan untuk pengujian dua sisi yaitu :

$\mathrm{H}_{0}: \beta=\beta \mathrm{o}$ (Variabel $\mathrm{X}$ tidak berpengaruh terhadap variabel $\mathrm{Y}$ secara signifikan)

$\mathrm{H}_{1}: \beta>\beta$ o (Variabel $\mathrm{X}$ berpengaruh terhadap variabel Y secara positif)

$\mathrm{H}_{1}: \beta<\beta$ o (Variabel $\mathrm{X}$ berpengaruh terhadap variabel $\mathrm{Y}$ secara negatif)

Langka selanjutnya dengan menentukan nilai probabilitas atau signifikansi $(\propto) \mathrm{t}_{\mathrm{x}, \mathrm{t}_{\mathrm{x}} / 2} \rightarrow$ Degree Of Freedom $(\mathrm{DF})=\mathrm{n}-\mathrm{k}(\mathrm{k}=$ banyaknya semua variabel $)$

to $=\frac{b-b o}{S b}$

Kemudian membuat kesimpulan untuk uji satu sisi (one-tailed test) :

Jika to $>\mathrm{t}$, maka $\mathrm{H}$ o ditolak.

Jika to $\leq \mathrm{t}$, maka Ho diterima atau,

Jika to $<-\mathrm{t}$, maka $\mathrm{H}$ o ditolak.

Jika to $\geq-\mathrm{t}$, maka Ho diterima.

Untuk uji dua sisi yaitu : 


\section{StatMat}

Jika to $>t_{x} / 2$ atau to $<-t_{x} / 2$, maka Ho ditolak.

Jika $-\mathrm{t}_{\mathrm{x} / 2} \leq$ to $\leq \mathrm{t}_{\mathrm{x}} / 2$, maka $\mathrm{H}_{0}$ diterima.

\section{HASIL DAN PEMBAHASAN}

\subsection{Hasil Data Penelitian}

Data yang tealh dikumpulkan, diinput dan diolah kemudian dianalisis untuk diambil kesimpulannya. Data awal yang dikumpulkan seperti pada tabeel dibawah ini :

Tabel 4.1 Data awal yang berisi harga pengawet serta kebutuhannya

\begin{tabular}{|c|c|c|c|c|c|c|c|c|c|c|c|c|}
\hline 离 & 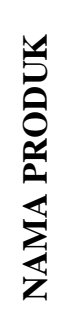 & 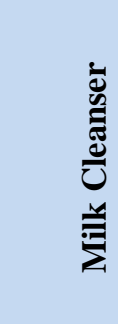 & $\begin{array}{l}\tilde{5} \\
\overline{\bar{a}}\end{array}$ & 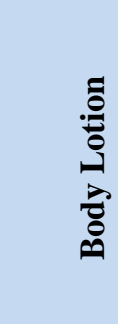 & 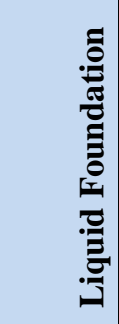 & 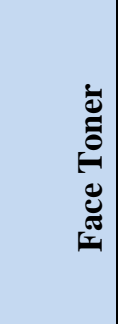 & 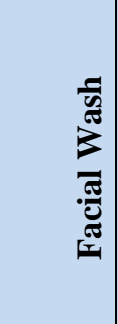 & 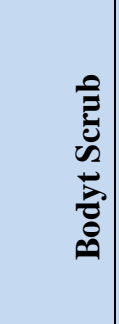 & 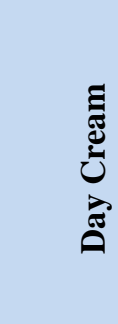 & 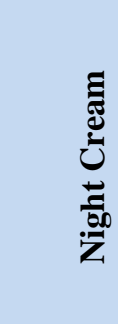 & 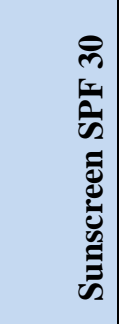 & 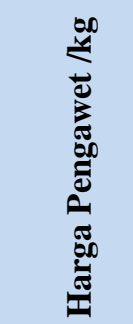 \\
\hline $31 / 07$ & \multirow{20}{*}{$\underset{v}{0}$} & 1000 & 1000 & $\mathbf{0}$ & 2000 & 0 & 0 & 960 & $\mathbf{0}$ & $\mathbf{0}$ & 0 & 2150000 \\
\hline $01 / 08$ & & 0 & 3000 & 1000 & 0 & 1000 & 1000 & 0 & 0 & 0 & 0 & 2000000 \\
\hline $02 / 08$ & & 0 & 960 & 1920 & 960 & 0 & 1000 & 0 & 5000 & 960 & 2000 & 2430000 \\
\hline $03 / 08$ & & 1000 & 1000 & 960 & 960 & 1000 & 1000 & 0 & 9000 & 1920 & 1000 & 2550000 \\
\hline $04 / 08$ & & $\mathbf{0}$ & 0 & 960 & 0 & $\mathbf{0}$ & 0 & 600 & 5000 & 1920 & 0 & 2100000 \\
\hline $07 / 08$ & & 0 & $\mathbf{0}$ & 0 & 960 & $\mathbf{0}$ & 2000 & 960 & 5000 & 1920 & 1000 & 1980000 \\
\hline 08/08 & & $\mathbf{0}$ & $\mathbf{0}$ & 960 & 960 & $\mathbf{0}$ & 1000 & 960 & 2000 & 960 & 1000 & 1980000 \\
\hline $09 / 08$ & & 1000 & 0 & 960 & 0 & 1000 & 2000 & 600 & 3000 & 0 & 1000 & 2150000 \\
\hline $10 / 08$ & & 1000 & 0 & 960 & 0 & 1000 & 1000 & 600 & 5000 & 960 & 1000 & 2200000 \\
\hline $11 / 08$ & & 2000 & 2000 & 5000 & 2000 & 2000 & 5000 & 8200 & 9000 & 7000 & 5000 & 2000000 \\
\hline $14 / 08$ & & 1000 & 0 & 960 & 0 & 1000 & 1000 & 600 & 5000 & 960 & 1000 & 2350000 \\
\hline $15 / 08$ & & 2000 & 2000 & 5000 & 2000 & 2000 & 5000 & 8200 & 5000 & 7000 & 5000 & 2150000 \\
\hline $16 / 08$ & & $\mathbf{0}$ & $\mathbf{0}$ & $\mathbf{0}$ & 0 & 0 & 0 & 0 & 2000 & 0 & 0 & 2000000 \\
\hline $17 / 08$ & & $\mathbf{0}$ & 0 & $\mathbf{0}$ & 0 & 0 & 0 & 0 & $\mathbf{0}$ & 0 & 0 & 2150000 \\
\hline $18 / 08$ & & 0 & 0 & 2000 & 960 & 0 & 1000 & 0 & 2880 & 960 & 2000 & 2000000 \\
\hline $21 / 08$ & & 0 & 1000 & 1000 & 2000 & $\mathbf{0}$ & 1000 & 0 & 1920 & 1920 & 1000 & 2430000 \\
\hline $22 / 08$ & & 1000 & 1000 & $\mathbf{0}$ & 960 & 1000 & $\mathbf{0}$ & $\mathbf{0}$ & 2880 & 1920 & $\mathbf{0}$ & 2550000 \\
\hline $23 / 08$ & & 1000 & O & 0 & O & 1000 & 2000 & $\mathbf{0}$ & 2880 & 1920 & 1000 & 2100000 \\
\hline $24 / 08$ & & 3000 & 2000 & 0 & $\mathbf{0}$ & 3000 & $\mathbf{0}$ & $\mathbf{0}$ & 2880 & 960 & 1000 & 1980000 \\
\hline $25 / 08$ & & $\mathbf{0}$ & 1000 & 0 & 0 & $\mathbf{0}$ & 0 & 0 & 3840 & 0 & 1000 & 1980000 \\
\hline \multicolumn{2}{|c|}{$\begin{array}{c}\text { \% Pengawet } \\
\text { yang } \\
\text { digunakan }\end{array}$} & 0,006 & 0,006 & 0,008 & 0,007 & 0,006 & 0,01 & 0,01 & 0,005 & 0,006 & 0,01 & \\
\hline
\end{tabular}

Sumber : Data rekapitulasi harian (PT Paragon Technology And Innovation)

Kemudian dari data diatas akan diambil total banyaknya pengawet yang digunakan dalam satu hari. Disajikan dalam tabel berikut :

Tabel 4.2 Kesimpulan total pengawet yang digunakan 


\begin{tabular}{|c|c|c|}
\hline Tanggal & Total Pengawet Yang Digunakan (kg) & Harga Pengawet per kg \\
\hline $31 / 07$ & 0,356 & 2150000 \\
\hline $01 / 08$ & 0,42 & 2000000 \\
\hline $02 / 08$ & 0,886 & 2430000 \\
\hline $03 / 08$ & 1,0892 & 2550000 \\
\hline $04 / 08$ & 0,502 & 2100000 \\
\hline $07 / 08$ & 0,8284 & 1980000 \\
\hline $08 / 08$ & 0,5976 & 1980000 \\
\hline $09 / 08$ & 0,7068 & 2150000 \\
\hline $10 / 08$ & 0,7644 & 2200000 \\
\hline $11 / 08$ & 3,59 & 2000000 \\
\hline $14 / 08$ & 0,7644 & 2350000 \\
\hline $15 / 08$ & 3,39 & 2150000 \\
\hline $16 / 08$ & 0,1 & 2000000 \\
\hline $17 / 08$ & 0 & 2150000 \\
\hline $18 / 08$ & 0,7288 & 2000000 \\
\hline $21 / 08$ & 0,6912 & 2430000 \\
\hline $22 / 08$ & 0,5064 & 2550000 \\
\hline $23 / 08$ & 0,6792 & 2100000 \\
\hline $24 / 08$ & 0,7816 & 1980000 \\
\hline $25 / 08$ & 0,352 & 1980000 \\
\hline & & \\
\hline & 0 & \\
\hline
\end{tabular}

\subsection{Hasil Perhitungan dan Pembahasan}

Dari hasil penelitian yang sudah dijabarkan dalam sub bab sebelumnya, akan dihitung menggunakan program SPSS. Langkah-langkahnya sebagai berikut:

\subsubsection{Analisis kenormalan data dengan skewness dan kurtosis}

Pada Bab III Poin 3.6.1 telah didapatkan tabel statistics nya sehingga kita hanya perlu menghitung nilai skewness dan nilai kurtosisnya. 
Tabel 4.3 Tabel statistics yang dihasilkan

\begin{tabular}{|l|r|r|}
\hline \multicolumn{3}{|c|}{ Statistics } \\
\hline \multirow{2}{*}{ Valid } & $\begin{array}{c}\text { Harga_Penga } \\
\text { wet }\end{array}$ & $\begin{array}{c}\text { Pemakaian_- } \\
\text { Pengawet }\end{array}$ \\
Skewness & 20 & 20 \\
Std. Error of Skewness & 0 & 0 \\
Kurtosis &, 949 & 2,465 \\
Std. Error of Kurtosis &, 512 &, 512 \\
\end{tabular}

Nilai Skewness $=\frac{\text { Skewness }}{\text { Std.Error of skewness }}$

Nilai Kurtosis $=\frac{\text { Kurtosis }}{\text { Std.Error of kurtosis }}$

1) Berdasarkan harga pengawet :

Nilai Skewness $=\frac{0,949}{0,512}=1,8535$

$$
\text { Nilai Kurtosis }=\frac{-0,368}{0,992}=-0,3709
$$

2) Berdasarkan pemakaian pengawet :

Nilai Skewness $=\frac{2,465}{0,512}=4,8144$

Nilai Kurtosis $=\frac{5,608}{0,992}=5,6532$

Karena nilai skewness dan kurtosis pada harga pengawet dan pemakaian pengawet diantara \pm 2 maka data tersebut adalah normal.

\subsubsection{Analisis kenormalan data dengan nilai $\mathrm{Z}$ Score.}

Pada Bab III Gambar 3.6. telah didapatkan nilai Z Score muncul sebagian besar terletak diantara $\pm 1,96$ maka data tersebut adalah normal.

\subsubsection{Uji Homogenitas dengan SPSS}

\section{Tabel 4.4 Tabel Uji Homogenitas}

Dari output di dapat nilai signifikansi sebesar 0,077 lebih besar dari 0,05 yang

\section{Test of Homogeneity of Variances}

Pemakaian_Pengawet

\begin{tabular}{|c|c|c|c|}
\hline $\begin{array}{l}\text { Levene } \\
\text { Statistic }\end{array}$ & df1 & $\mathrm{df} 2$ & Sig. \\
\hline 2,653 & 5 & 12 & .077 \\
\hline
\end{tabular}

berarti bahwa sampel diambil dari populasi yang mempunyai varian yang sama. 
3.2.4. Analisis Korelasi antara variabel dependen dan variabel independen.

Tabel 4.5 Tabel Korelasi

\begin{tabular}{|ll|r|r|}
\multicolumn{4}{|c|}{ Correlations } \\
\hline & Pearson Correlation & $\begin{array}{r}\text { Harga_Penga } \\
\text { wet }\end{array}$ & $\begin{array}{r}\text { Pemakaian_- } \\
\text { Pengawet }\end{array}$ \\
\hline Harga_Pengawet & 1 &,- 044 \\
& Sig. (2-tailed) & 20 &, 853 \\
& N &,- 044 & 20 \\
\hline Pemakaian_Pengawet & Pearson Correlation &, 853 & 1 \\
& Sig. (2-tailed) & 20 & 20 \\
& N &
\end{tabular}

Setelah itu memulai pengujiannya

Analisis :

1. Hipotesis

H0 : Tidak ada hubungan antara variabel (tidak ada hubungan antara kenaikan harga pengawet dengan pemakaian pengawet pada kegiatan produksi)

H1 : Ada hubungan antara variabel (ada hubungan antara kenaikan harga pengawet dengan pemakaian pengawet pada kegiatan produksi)

2. Pengambilan Keputusan

a. Berdasarkan Probabilitas

Syarat :

- Jika probabilitas >0,05 maka H0 diterima

- Jika probabilitas < 0,05 maka H0 ditolak

Terlihat pada output bahwa probabilitas antara harga pengawet dengan pemakaian pengawet $=0,853>0,05$ maka $\mathrm{H} 0$ diterima yang artinya tidak ada hubungan antara variabel atau dengan kesimpulan tidak ada hubungan antara kenaikan harga pengawet dengan pemakaian pengawet pada kegiatan produksi.

b. Berdasarkan Angka Korelasi

Syarat :

- Arah korelasi positif dan angka korelasi > 0,5 maka memilki hubungan kuat

- Arah korelasi negatif dan angka korelasi < 0,5 maka memiliki hubungan lemah

Dari output terlihat angka korelasi antara harga pengawet dengan pemakaian pengawet adalah $-0,044<0,5$ yang artinya antara harga pengawet dengan pemakaian pengawet memiliki hubungan lemah.

3.2.5. Analisis Regresi untuk menemukan persamaan regresi yang menunjukan hubungan antara variabel dependen (variabel respon) dengan satu atau beberapa variabel independen (variabel prediktor). Dimana variabel dependen adalah pemakaian pengawet dan variabel independen adalah harga pengawet. Karena variabel independen hanya satu, maka analisis ini menggunakan analisis regresi sederhana. 
Tabel 4.6 Tabel Model Summary Koefisien Determinasi

Model Summary ${ }^{\mathrm{b}}$

\begin{tabular}{|l|c|r|r|r|r|}
\hline Model & $R$ & R Square & $\begin{array}{c}\text { Adjusted R } \\
\text { Square }\end{array}$ & $\begin{array}{c}\text { Std. Error of } \\
\text { the Estimate }\end{array}$ & $\begin{array}{c}\text { Durbin- } \\
\text { Watson }\end{array}$ \\
\hline 1 &, $044^{\mathrm{a}}$ &, 002 &,- 053 &, 9525633 & 2,127 \\
\hline
\end{tabular}

a. Predictors: (Constant), Harga_Pengawet

b. Dependent Variable: Pemakaian_Pengawet

Karena menggunakan analisis regresi linear sederhana sehingga yang dipakai untuk melihat koefisien determinasi adalah nilai $\mathrm{R}$. Terdapat koefisiensi determinasi $\mathrm{R}$ yang berguna untuk mengetahui besarnya sumbangan pengaruh variabel independen terhadap variabel dependen yang dinyatakan dalam persentase $(0,044)$.

$$
0,044 \rightarrow 0,044 \times 100 \%=4,4 \%
$$

4,4\% merupakan besarnya pengaruh variabel independen harga pengawet terhadap variabel dependen pemakaian pengawet, sedangkan sisanya $=95,6 \%$ adalahb besarnya pengaruh faktor lain diluar variabel independen yang ada.

1. Uji Statistik F (Uji Anova)

a. Hipotesis

H0 : Tidak ada pengaruh antara harga pengawet dengan pemakaian pengawet

H1 : Ada pengaruh antara harga pengawet dengan pemakaian pengawet

b. Pengambilan Keputusan Berdasarkan Perbandingan Fhitung dengan Ftabel

Syarat :

H0 diterima : Jika Fhitung $<$ Ftabel

H0 ditolak : Jika Fhitung $>$ Ftabel

Pada output Fhitung (tabel ANOVA) : 0,035

Tabel 4.7 Tabel ANOVA

ANOVA $^{a}$

\begin{tabular}{|ll|r|r|r|r|r|}
\hline \multicolumn{1}{|l|}{} & \multicolumn{1}{c|}{$\begin{array}{c}\text { Sum of } \\
\text { Squares }\end{array}$} & $\mathrm{df}$ & Mean Square & $\mathrm{F}$ & Sig. \\
\hline 1 & Regression &, 032 & 1 &, 032 &, 035 &, $853^{\mathrm{b}}$ \\
& Residual & 16,333 & 18 &, 907 & & \\
& Total & 16,365 & 19 & & & \\
\hline
\end{tabular}

a. Dependent Variable: Pemakaian_Pengawet

b. Predictors: (Constant), Harga_Pengawet

Untuk menentukan Ftabel :

$\alpha=0,05$

Prob $=1-\alpha=0,95$

$D F_{1}=$ banyak variabel $-1=2-1=1$

$D F_{2}=N-k-1=20-1-1=18$

Dengan $N$ adalah banyaknya data yang diteliti dan $k$ banyak variabel independen.

Sehingga diperoleh : $F_{\text {tabel }}=(4,41)$ 
Keputusan H0 diterima karena $F_{\text {hitung }}<F_{\text {tabel }}$

Kesimpulan :

Tidak ada pengaruh antara harga pengawet dengan pemakaian pengawet.

c. Pengambilan Keputusan Berdasarkan Nilai Probabilitas

Syarat :

H0 diterima : jika nilai probabilitas $>0,05$

H0 ditolak : jika nilai probabilitas $<0,05$

Diketahui sig.(tabel ANOVA) : 0,853 (>0,05)

Keputusan $\mathrm{H} 0$ diterima karena probabilitas $>0,05$

Kesimpulan :

Tidak ada pengaruh antara harga pengawet dengan pemakaian pengawet.

2. Uji Statistik T

Pada kasus diatas menggunakan regresi linear sederhana, bentuk umum persamaan regresi : $Y=a_{1} X_{1}+C$

Pada output tabel Coefficient hasil perhitungan diatas dapat dibuat persamaan regresi $Y=-2,104 \mathrm{E}-7 X_{1}+1,341$

Tabel 4.8 Tabel Coefficient

Coefficients $^{a}$

\begin{tabular}{|c|c|c|c|c|c|c|c|c|}
\hline \multirow[b]{2}{*}{ Model } & & \multicolumn{2}{|c|}{ Unstandardized Coefficients } & \multirow{2}{*}{$\begin{array}{c}\begin{array}{c}\text { Standardized } \\
\text { Coefficients }\end{array} \\
\text { Beta } \\
\end{array}$} & \multirow[b]{2}{*}{$t$} & \multirow[b]{2}{*}{ Sig. } & \multicolumn{2}{|c|}{ Collinearity Statistics } \\
\hline & & $B$ & Std. Error & & & & Tolerance & VIF \\
\hline 1 & (Constant) & 1,341 & 2,424 & &, 553 &, 587 & & \\
\hline & Harga_Pengawet & $-2,104 \mathrm{E}-7$ &, 000 &,- 044 &,- 188 & 853 & 1,000 & 1,000 \\
\hline
\end{tabular}

a. Dependent Variable: Pemakaian_Pengawet

Dimana :

$Y=$ Pemakaian pengawet

$X_{1}=$ Harga pengawet

$C=$ Konstanta

Dari persamaan tersebut menunjukan bahwa :

a. Koefisien regresi X1 sebesar -2,104E-7 menyatakan bahwa setiap penambahan Rp. 1 harga pengawet akan meningkatkan pemakaian pengawet sebesar -2,104E7.

b. Konstanta sebesar 1,341 menyatakan bahwa jika variabel bebas harga pengawet tidak ada maka pemakaian pengawet adalah 1,341.

\section{KESIMPULAN}

Berdasarkan hasil penelitian dan pemahasan dapat diambil kesimpulan yaitu:

1. Ada pengaruh kenaikan harga pengawet terhadap kegiatan produksi di industri kosmetik sebesar 0,044 walaupun tidak secara signifikan. 
2. Persamaan untuk mengetahui apakah terdapat pengaruh antara kenaikan harga pengawet terhadap kegiatan produksi adalah :

$Y=-2,104 \mathrm{E}-7 X_{1}+1,341$

\section{DAFTAR PUSTAKA}

E, Walpole, Roland.(1992) Pengantar Statistika, Edisi ke-3, Gramedia, Jakarta Sarwono, Jonathan. dan Nur Salim, Hendra.(2016) Prosedur-prosedur Populer Statistik untuk Analisis Data Riset Skripsi, Penerbit Gava Media, Yogyakarta Sarwono, Jonathan.(2009) Statistik itu mudah: Panduan Lengkap Untuk Belajar Komputasi Statistik Menggunakan SPSS 16, $\quad$ Penerbit Andi, Yogyakarta 